\title{
Water Harvesting as a Technological Innovation and Greater Solving of Climatic Change Impact to Supply Fertigation
}

\author{
Nurpilihan Bafdal $^{\#}$, Sophia Dwiratna ${ }^{\#}$, Edy Suryadi", Dwi Rustam Kendarto ${ }^{\#}$ \\ ${ }^{\#}$ Department of Agriculture and Biosystem Engineering, Universitas Padjadjaran, Sumedang Km. 21 40600, Indonesia \\ E-mail: nurpilihanbafdal@yahoo.com
}

\begin{abstract}
Water is one critical factor in the agriculture sector and becomes the first barrier in agriculture production. In the dry season, water availability without depending on the season expertise should be able to find the technological innovation that can be used to the farmers, especially in the rural areas. Global climate change caused more long dry season and will impact to decrease of water from rainfall and runoff. Rainfall and runoff harvesting it means capturing water from rainfall where it falls or capturing in and can be stored it the torrents and ponds and good enough for resources of fertigation. Fertigation engineering is the application of supplying irrigation and fertilizer to crops and engineering principles to the solution of water management problem. Research of water harvesting with cultivated of red oval cherry tomato and planted was carried out at the greenhouse located in Universitas Padjadjaran Campus, West Java Province, Indonesia from January to Mei 2017. The research method is descriptive analysis, and the red oval tomato planted it on the autopot with growth media uses mixed of charcoal husk and zeolite with ratio 9: 1 and $15 \mathrm{~cm}$ height. The amount of water harvesting from the green house' rooftop is 20200,5 liter per year.The amount of water used by tomato plant used auto pot is 427,12 liter. The research shows that the water used of red oval tomato where for initial stage 66 liter; development stage 36,22 liter; midseason stage 310,04 liter and late seasons stage 14,86 liter; average total water used for red oval tomato at 8,21 liter/plant. The average yield of red oval tomato per plants using autopot where the lowest yield was $0.731 \mathrm{~kg} / \mathrm{plant}$ while the highest yield of $1.648 \mathrm{~kg} / \mathrm{plant}$. The value of water use efficiency of red oval tomato is $10 . \mathrm{kg} / \mathrm{m3}$.
\end{abstract}

Keywords — climate change; water harvesting; fertigation; autopot; water used efficiency.

\section{INTRODUCTION}

Water is one critical factor in the agriculture sector and becomes a first barrier factor in agriculture production. The limitation of water resources availability may cause irrigation requirement and more competitive. To actualize fairly and equality, the Indonesian Government settled the regulation on irrigation management which should fundamentally be adhered participatory and whose implementation engaged farmer's role. In the dry season, water availability for irrigation is a problem that have to overcome, to keep water availability without depending on the seasoned expertise should be able to find the technological innovation that can be used to the farmers especially in the rural areas [1]. Global climate change caused more long dry season and will impact to decrease of water from rainfall and runoff. Rainfall harvesting is one of alternative the solution because water could be collected in a wet season, and stored it to the tank or torrents and can be applied for irrigation [2], [3]. Supply and demand between on water and plants and the decrease of water for irrigation resource stability breed the need to water saving.
Nurpilihan et al. [4], [5] noted that water uses different with numerous and period stage of plants. Increasing demands of water and with limited supplies available; in this case need more efficient of water use; or water conservation in the soil; increasing water used of efficiency can become an alternative to prevent water deficiency.

\section{A. Water Harvesting}

Rainfall harvesting it means capturing rainfall where it falls or capturing the run off in own urban or rural areas[3], [6]. Rainfall harvesting can be undertaken through a variety of ways these are:

1. Capturing rainfall from the rooftop

2. Capturing rainfall from local catchments

3. Capturing seasonal floodwaters from local streams, and

4. Conserving water by applying watershed management.

In general, water harvesting is the activity of direct collection of rainwater. The rainfall collected can be stored for direct use or can be re-charged into the ground water[1], [7]. Rainfall collection and stored it in tanks actually not be used for drinking, kitchen or bathroom sinks unless it is potable water that cab consumed; but good enough for resources of irrigation; livestock water supply, washing 
clothing, flushing toilets or landscape watering in other words collected rainfall harvesting has proven the value of harvesting rainwater for outdoor use[8]-[12]. The collection of rainfall harvesting falling over an area cannot be effectively harvested because of evapotranspiration, spillage.

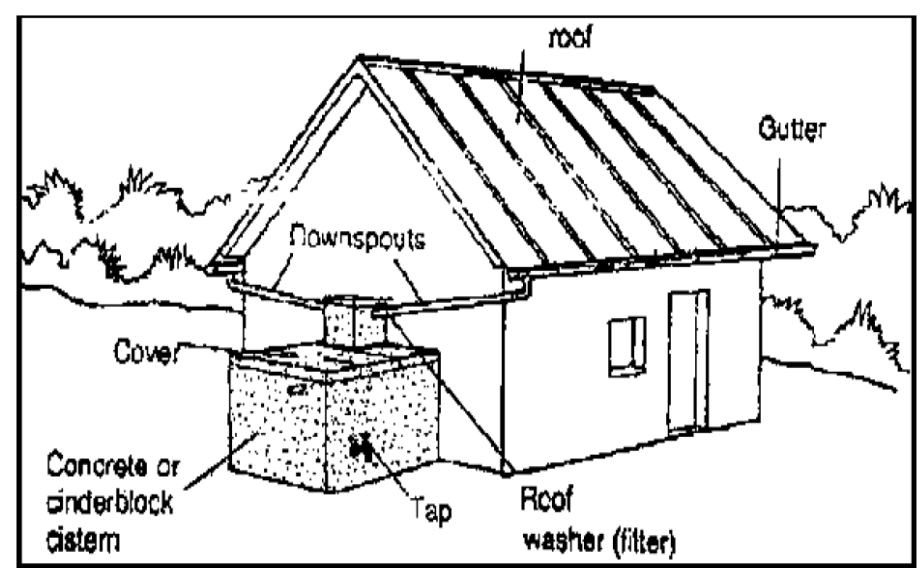

Fig 1. Rooftop Rainwater Harvesting System

\section{B. Global Climate Change}

Climate change, also called global warming is the rise in average surface temperatures on earth. Climate change is due primarily to the human use of fossil fuels, which release carbon dioxide and other greenhouse gases into the air.The gases trap heat within the atmosphere, which can have a range of effects on ecosystems, including rising sea level, severe weather events, and droughts that render landscapes more susceptible to wildfires.

Global climate change impact on crops because the temperature will rise, atmospheric carbon dioxide $(\mathrm{O} 2)$; the frequency and intensity of extream weather could have a significant impact on crop yields. For any particular crops, the effect of increased temperature will depend on the crop's optimal temperature for growth and reproduction. In some areas warmy may benefit the types of crops; that is currently gr in warmer areas conversely, if the higher temperature exeeds a crops optimum temperature, yield will decline. More extreme temperature and precipitation can prevent crops from growing; floods and droughts can harm crops and reduce yields, Rising $\mathrm{CO} 2$ can stimulate plant growth, reduces the nutritional value of most food crops. Figure 2 below showed the global climate change impact on length of dry season in campus Unpad at Jatinangor.

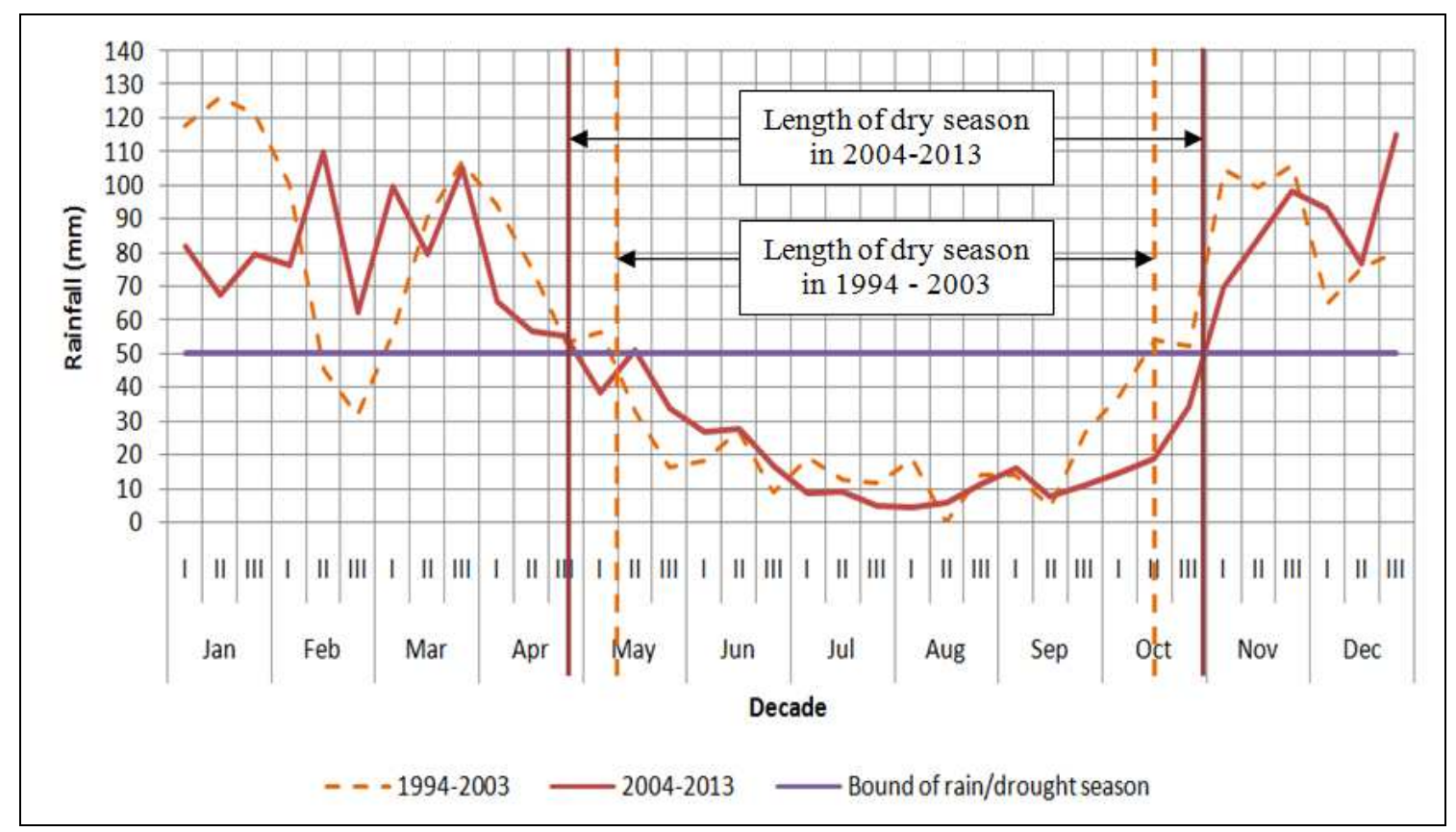

Fig. 2. Global climate change impact on length of dry season in Jatinangor, West Java, Indonesia

The dry season during 1994 - 2003 decade period started in first of ten days in May and ended in the second decade on October. But during 2004 - 2013 decade period, its start early and ended further than before. Its shown that during two decadal periods the global change impact on the length of dry season, which is the dry season start early and ended more length.

\section{Fertigation}

Water and nutrients are a basic requirements for plant growth, and performance and leaf water supply constitutes the overwhelming limitation on plant productivity[13]. The delivery of dissolved mineral fertilizers to the roots of crops in the field using irrigation water is known as fertigation[4]. The use of fertigation is gaining popularity because it is efficiencies in nutrient management time and labour and potentially greater control over the crop. Nurpilihan, et al. (2017)[4] noted that fertigation engineering is the application of supplying irrigation and fertilizer to crops and engineering principles to the solution of water management problem. The modern concept of irrigation such as fertigation has been made possible only by the application of 
modern power resources to rainfall harvesting and by storage to the big torrent or storage tank of water reservoirs. The advantages of supplying mineral nutrients to crop roots fertigation include:[14]-[16]

1. Reduced delivery costs because of no need to broadcast fertilizers, leading to less soil compaction in the interrow areas, less fuel usage and lower labour requirements)

2. Greater control over where and when nutrients are delivered, leading to greater use efficiency

3. More control over crop behaviour through the targeted application of specific nutrients during particular stages of crop development

4. The potential for reduced fertilizer losses (due to immobilization within or leaching below the root zone) by supplying small amount often.

Besides advantages of fertigation where have several disadvantaged these include[15]-[18]:

a. Greater capital costs with the equipment needed to dissolve and inject the fertilizer into the irrigation water

b. Higher operating costs using technical grade fertilizer as opposed to agricultural grade fertilizers

c. The chemical reaction between some types of fertilizer when mixed potentially causing significant equipment blockages.

Grade fertilizer is generally not suitable to use fertilizer system because of the amount of impurities present which may be insoluble and lead to dripper blockages. For this reason, technical grade fertilizers are normally required in fertigation systems because they have fewer impunities and proportionally higher levels of the desired mineral nutrients. Using fertigation is to manage crop performance need to be based on a good knowledge of when and to what extend each mineral nutrient is taken up by the crop's root and how it affects crop growth development and yield. Another gap in this technology is the ability to measure crop nutrient status in real time and to interpret that information correctly and use it to manage to fertigation system[14].

The autopot is one of latest technology an efficient and environment-friendly technology that revolves around the Smart valve, which feeds plants on demand. Fertigation combined with autopot fed with nutrient-rich water, crop is protected from soil-borne diseases and are kept healthy without the use of harmful chemicals. The autopot is one of latest technology an efficient and environment-friendly technology that revolves around the SmartValve, which feeds plants on demand. Fertigation combined with autopot fed with nutrient-rich water, crop is protected from soil borne diseases and are kept healthy without the use of harmful chemical.

Combined between fertigation and autopot is one of new technology today to increase agriculture productivity. Through the use of this technology, we have developed a sustainable method of farming that does not depend on soil condition. And can be applied almost anywhere, we have applied our agricultural system to provide a livelihood to rural folk who previously had no means to support themselves.

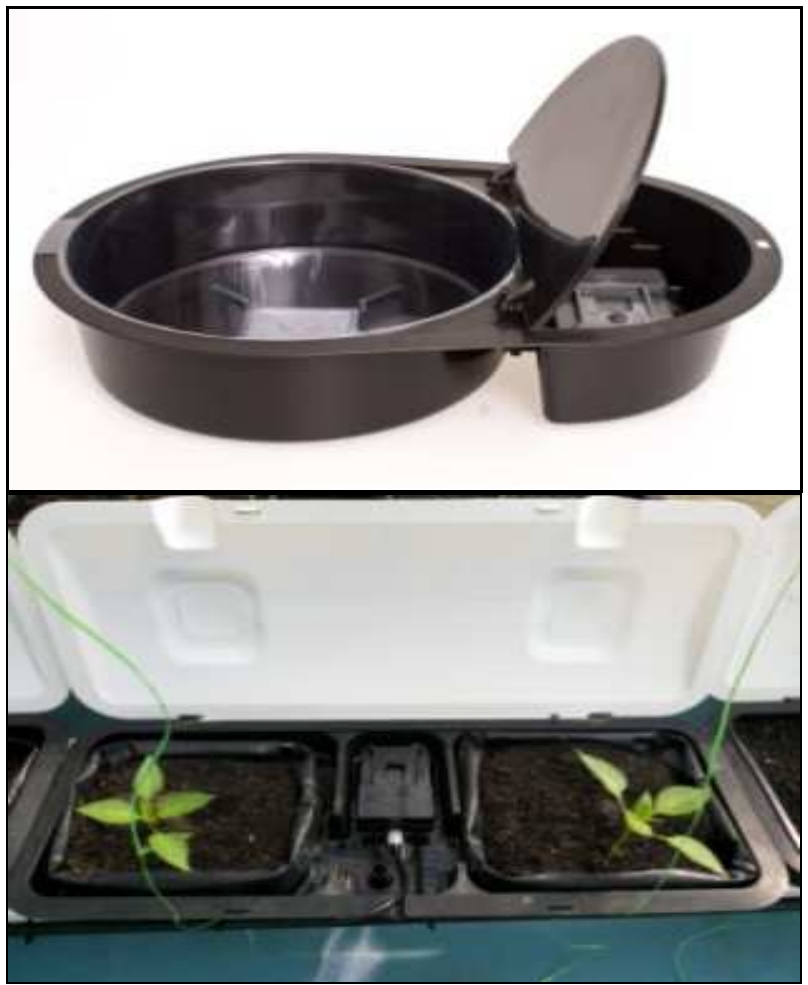

Fig 3. Single and Double Tray Autopot with Smart-valve[2]

There are some benefit of autopot. These are[19]: (i) resource efficiency; there is no water wastage, or nutrient came out from the autopot as plant feed on demand. (ii) environmentally friendly; without nutrient and water from fertigation came out from the autopot; there is pollution to surrounding water systems. (iii) flexibility; the system allows agriculture to thieves in areas that would normally be seen as non-conductivity to farming such as non productive or marginal land or even rooftops. (iv) automatic and simple; this system is fully automated, farming on a commercial scale become easier and less laborious, and (v) consistent; crop yield quantity and quality are consistent.

\section{MATERIALS AND METHODS}

The research was carried out at the green house located in Universitas Padjadjaran, West Java Province, Indonesia from January to Mei 2017. The research method is descriptive analysis with cultivated of red oval cherry tomato and planted it on the autopot with growth media uses mixed of charcoal husk and zeolite with ratio 9:1 and $15 \mathrm{~cm}$ height.

Plant nutrients stored in a small tank than applied it in to the autopot through the main pipe and lateral pipe which is connected to smart valve. Irrigation resources from rainfall harvesting which capture from rooftop the green house and collected in four the big torrents at outdoor the green house. The research observed as follow:

a. Calcultated potential of rainwater that could be harvested

Rainwater that can be harvested is calculated using the following equation[20]:

$\mathrm{V}=\mathrm{A} \times \mathrm{R} \times \mathrm{c}$

Whereas, $\mathrm{V}$ is the volume of potential rainwater that could be harvested $\left(\mathrm{m}^{3}\right)$; A, rooftop area $\left(\mathrm{m}^{2}\right)$; $\mathrm{R}$, the annual probability with $80 \%$ probability exceeded $(\mathrm{mm})$; and c, runoff coefficient. 
b. Water consumptive use

Consumptive water is the total amount of water used by plants (ETc). Consumptive water measurements are done every day at 07.00 by measuring the reduction of water in nutrient drums. Nutrition drums connect directly to autopot via pipelines.

c. The yield of red oval cherry tomato

d. Water used efficiency

The efficiency of water use (WUE) is the result of harvest produced with the required water. According to Nurpilihan et al. (2017)[4], water use efficiency (WUE) can be calculated using the equation below:

WUE $=\frac{\text { Total Yield }}{\text { Total Water Use }}$

Where total yield is expressed in $\mathrm{kg}$, total water use expressed in $\mathrm{m}^{3}$ and water use efficiency (WUE) is expressed in $\mathrm{kg} \cdot \mathrm{m}^{-3}$.

\section{RESULTS AND DISCUSSION}

\section{A. Potential of rainwater that could be harvested}

Research on rainwater harvesting as a source of irrigation water is done by harvesting rainfall from the roof of a greenhouse as illustrated in Figure 4. Rainwater falling on the roof is captured and flowed to the gutter and then collected in two container tanks and distribution tanks. The water then flowed into the nutrient tank inside the greenhouse and then flowed into the autopot fertigation network.

The catchment area of the greenhouse rooftop is $150 \mathrm{~m}^{2}$. Greenhouse rooftop is made of polycarbonate material with runoff coefficient value of 0.90 ; it means that $90 \%$ of the rain falling on the rooftop will become a runoff. Dwiratna and Nurpilihan (2016) state that annual rainfall with an $80 \%$ probability is exceeded at the research site is $1500 \mathrm{~mm}$. Thus, the amount of rainwater that can be harvested from the rooftop of the greenhouse is $202.5 \mathrm{~m}^{3}$ per year. In the study, the volume of storage used was $11 \mathrm{~m}^{3}$.

\section{B. Water consumptive use}

The value of plant evapotranspiration (ETc) is derived from consumptive water use by the plant as calculated from the water depletion on the nutrient drum each day. The amount of water used by cherry tomato plants in each growing phase can be seen in Table 1 . In the Table, it can be seen that the total water used for cherry tomato plants in one period grows at 8.21 liters / plant.

Water use continues to increase in each phase, and there is a decrease in the late season phase. The most water use is in the mid-season phase of 5.96 liters/plant and the least use of water in the late seasion phase of 0.29 liters/plant. The total water requirement of red oval tomato plants during one planting period using autopot is $378 \mathrm{~mm}$. According to FAO data the total requirement of red oval tomato plant; water is $600 \mathrm{~mm}$. Figure 5 shows the comparison of ETc values of measurements with ETc resulting from FAO.

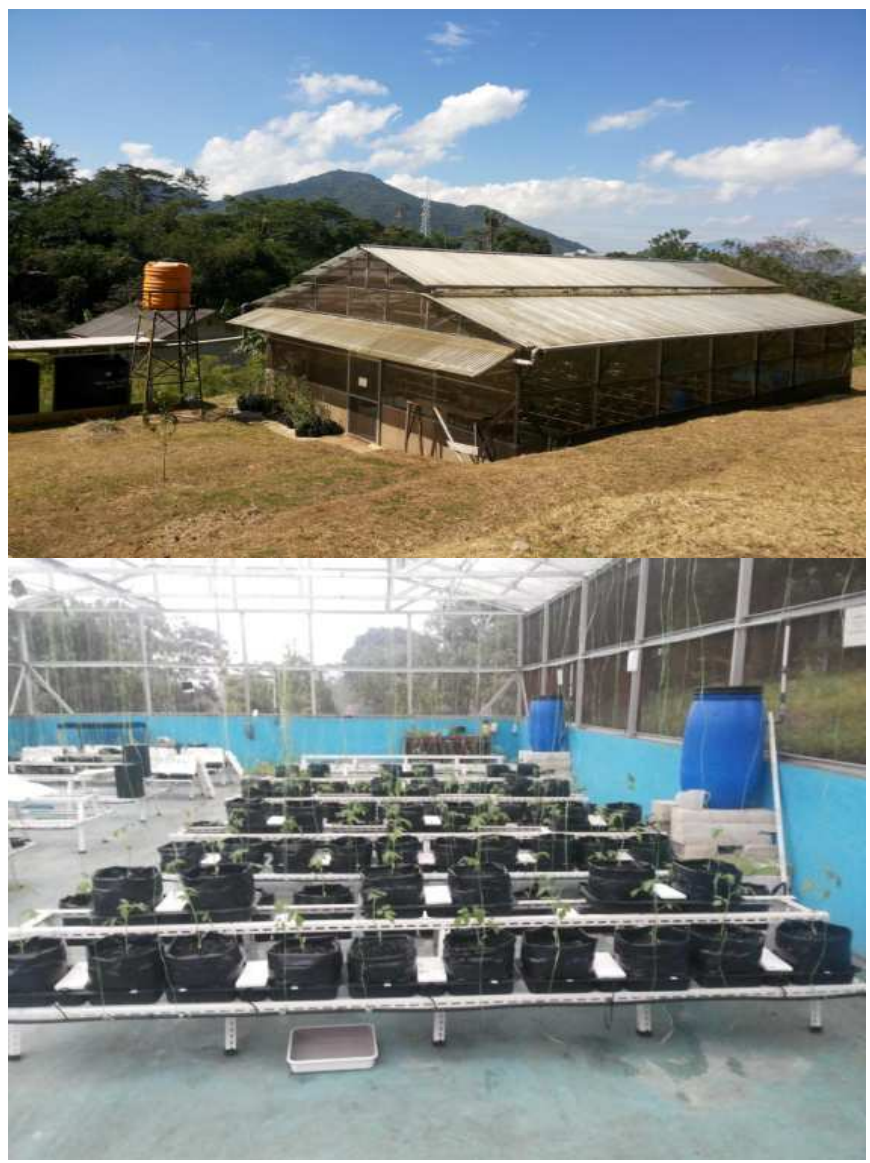

Fig. 4. Rainwater harvesting system and autopot fertigation network

TABLE I

WATER CONSUMPTIVE USE OF RED OVAL CHERRY TOMATO

\begin{tabular}{|c|c|c|c|}
\hline \multirow[t]{2}{*}{ Growth State } & \multirow{2}{*}{$\begin{array}{c}\text { Total } \\
\text { Water Use } \\
\quad \text { (liter) }\end{array}$} & \multicolumn{2}{|c|}{$\begin{array}{c}\text { Average Water } \\
\text { Consumptive Use Per } \\
\text { Crop }\end{array}$} \\
\hline & & Liter & mm/day \\
\hline Initial (20 day) & 66,00 & 0,33 & 1.03 \\
\hline Development (20 day) & 36,22 & 0,70 & 2.00 \\
\hline Mid Season (95 day) & 310,04 & 5,96 & 3.38 \\
\hline Late Seasion (10 day) & 14,86 & 0,29 & 1.56 \\
\hline Total & 427,12 & 8,21 & \\
\hline
\end{tabular}

From Figure 5 it can be seen that the value of plant evapotranspiration (ETc) increases with the growth and development of the plant and then decreases at the late season of planting. ETc value in the initial phase is $1.03 \mathrm{~mm}$ / day at the age of plants of 1-20 days, ETc value in the development phase at 21-39 days after planting of $2.00 \mathrm{~mm} /$ day, The value of ETc in the mid-season phase of the plant age 40-135 days after planting ie $3.38 \mathrm{~mm} /$ day and in the late season phase of ETc value of $1.56 \mathrm{~mm} /$ day at the plant age of 136-145 days after planting. When compared to FAO data the use of water to meet the water needs of red oval tomato plants using autopot technology uses more efficient. 


\section{Red oval cherry tomato yields}

The way to determine the harvest index is to distinguish the physical-chemical changes that occur during the fruit ripening process from the maturity level of young to old, green mature, breaker, turning, pink, light red and red respectively[21]-[23]. Flowering starts to occur when the plant is three weeks after planting (WAP), and flowers begin to bloom (anthesis) when the plant enters the age of 4 WAP. The fruit has already set to form when the plant is 5 WAP.
The first harvest started when the plant was 8 WAP. According to Rubatzky and Yamaguchi (1999), the time of cultivation to first fruit harvesting depends on cultivars and growth conditions, and can range from 70 days to 125 days; most red oval tomatoes mature 35-60 days after the plant (912 WAP). Harvesting is done periodically that is $2-3$ days interval once. The measurement of red oval tomato yield is done by weighing fruit per plant.

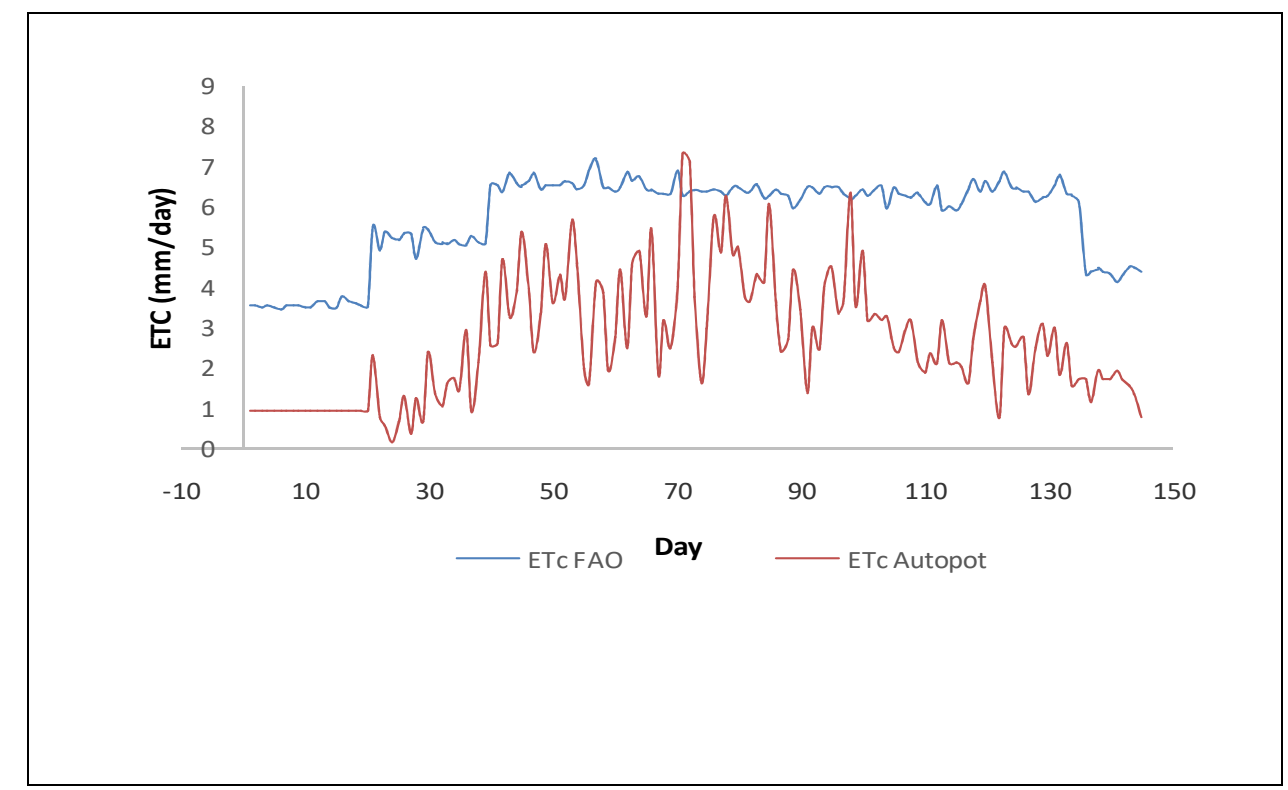

Fig. 5. Value comparison Consumption use of cherry tomato water using autopot And FAO standard

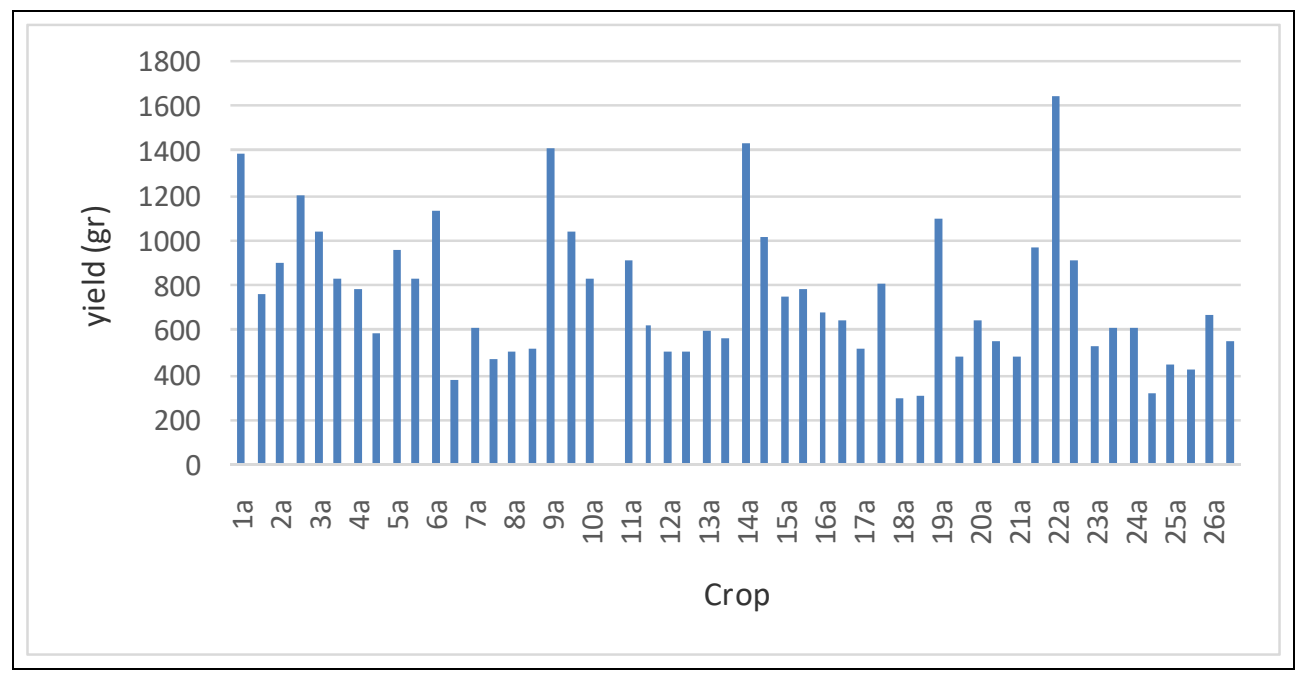

Fig. 6. Total Yield of Red Oval Tomato per Plant

The results of the observation of red oval tomato plant production using autopot can be seen in Figure 6. The lowest weight of crop yields is $0.731 \mathrm{~kg}$, and the highest yield is obtained from a red oval tomato plant that is $1,648 \mathrm{~kg}$ of harvest Total crop yield of red oval tomatoes using autopot is $38.04 \mathrm{~kg}$ or $47.55 \mathrm{ton} / \mathrm{ha}$. When compared with FAO data stating that the production of tomatoes on irrigated land is 45 ton/ha; while red oval tomato cultivation using fertigation and autopot produces higher production.

\section{Water used efficiency}

The water use of efficiency (WUE) is calculated using Equation 2. Water use efficiency is the ratio of total yield per unit of water used. The results show that the efficiency of water use in red oval tomato cultivation using autopot is $10,35 \mathrm{~kg} / \mathrm{m}^{3}$. Low water use and high production can increase efficiency. This is supported by Nurpilihan statement, that the higher the crop yield, the higher the efficiency value of water use. The higher the use of water, 
the lower the efficiency. To increase the efficiency can be achieved by increasing the amount of dry matter or yield for each unit of water volume provided (Wiroatmojo, 1985).

\section{CONCLUSIONS}

The amount of rainfall potential that can be harvested from the greenhouse roof is $202.5 \mathrm{~m} 3$ per year, this value is sufficient to be used as an fertigation water source especially in the dry season. The average yield of red oval tomato plants using autopot the lowest yield is $0.731 \mathrm{~kg} /$ plant and the highest yield of $1,648 \mathrm{~kg}$. The value of water use efficiency of red oval using autopot is $10.35 \mathrm{~kg} / \mathrm{m} 3$.

\section{ACKNOWLEDGEMENT}

The authors would like to thank the Rector of Universitas Padjadjaran for the Academic Leadership Grant's funding, trough internal grant number 431/UN6.431/PL/2018.

\section{REFERENCES}

[1] S. Dwiratna, N. Bafdal, C. Asdak, and N. Carsono, "Study of Runoff Farming System to Improve Dryland Cropping Index in Indonesia," Int. J. Adv. Sci. Eng. Inf. Technol., vol. 8, no. 2, pp. 390-396, 2018.

[2] N. Bafdal, S. Dwiratna, D. R. Kendarto, and E. Suryadi, "Rainwater Harvesting As a Technological Innovation to Supplying Crop Nutrition through Fertigation," Int. J. Adv. Sci. Eng. Inf. Technol., vol. 7, no. 5, pp. 1670-1675, 2017.

[3] Nurpilihan, "Rainfall Harvesting as Resources of Self Watering Fertigation System with Various Growing Medias," Int. J. Adv. Sci. Eng. Inf. Technol., vol. 6, no. 5, pp. 787-792, 2016.

[4] Nurpilihan, S. Dwiratna, and D. R. Kendarto, "Impact of Water Use on Paprika ( Capsicum annum ) by Using Fertigation and Autopot System Combined with Numerous Growing Media," Asian J. Plant Sci., vol. 16, no. 3, pp. 149-159, 2017.

[5] B. Nurpilihan and S. Dwiratna, "Water Harvesting System as an Alternative Appropriate Technology to Supply Irrigation on Red Oval Cherry Tomato Production," Int. J. Adv. Sci. Eng. Inf. Technol., vol. 8, no. 2, pp. 561-566, 2018.

[6] Nurpilihan, S. Dwiratna, and D. R. Kendarto, "Runoff Management Technology for Integrated Dry Land Agriculture in Jatinangor Research Center West Java Indonesia," Egypt. J. Desert Res., vol. 65, pp. 1-11, 2015.

[7] S. Kumar, T. Ramilan, C. A. Ramarao, C. S. Rao, and A. Whitbread, "Farm-level rainwater harvesting across different agro-climatic regions of India: Assessing performance and its determinants," Agric. Water Manag., vol. 176, pp. 55-66, 2016.

[8] M. Napoli, S. Cecchi, S. Orlandini, and C. A. Zanchi, "Determining potential rainwater harvesting sites using a continuous runoff potential accounting procedure and GIS techniques in central Italy," Agric. Water Manag., vol. 141, pp. 55-65, 2014.

[9] N. Rostad, R. Foti, and F. A. Montalto, "Harvesting rooftop runoff to flush toilets: Concluding four major U.S. cities," Resour. Conserv. Recycl., vol. 108, 2016.

[10] K. J. An, Y. F. Lam, S. Hao, T. E. Morakinyo, and H. Furumai, "Multi-purpose rainwater harvesting for water resource recovery and the cooling effect," Water Res., vol. 86, 2015.

[11] W. H. Mahmoud, N. A. Elagib, H. Gaese, and J. Heinrich, "Rainfall conditions and rainwater harvesting potential in the urban area of Khartoum," Resour. Conserv. Recycl., vol. 91, pp. 89-99, 2014.

[12] P. A. Patel, M. D. Desai, and J. A. Desai, "Rooftop Rainwater Harvesting, Conservation and Management Strategies for Urban and Rural Sectors," in India Water Week 2012-Waetr, Energy and Food Security: Call for Solutions, 2012, no. April, pp. 10-14.

[13] P. J. Kramer and J. S. Boyer, Water Relations of Plants and Soils. California: Academic Press, 1995.

[14] M. Treeby, S. Falivene, and M. Skewes, "Fertigation: delivering fertiliser in the irrigation water," Primefact, no. DECEMBER 2006, p. 4, 2011.

[15] M. Kabirigi et al., "Fertigation for Environmentally Friendly Fertilizers Application: Constraints and Opportunities for Its Application in Developing Countries," pp. 292-301, 2017.

[16] R. A. Jat, S. P. Wani, K. L. Sahrawat, P. Singh, and B.. Dhaka, "Fertigation in Vegetable Crops for Higher Productivity and Resource Use Efficiency," Indian J. Fertil., vol. 7, no. 3, pp. 22-37, 2011.

[17] I. Papadopoulos, C. Metochis, and N. Seraphides, "Fertigation recipes for selected crops in the Mediterranean region," Cyprus, 2011.

[18] L. Incrocci, D. Massa, and A. Pardossi, "New Trends in the Fertigation Management of Irrigated Vegetable Crops," Horticulturae, vol. 3, no. 37, pp. 1-20, 2017.

[19] J. Fah, Hydroponics Made Easy: A Useful Guide for Novice and Intermediate Users of Hydroponics. Bayswater, Vic: Agromatic Corporation Pty Ltd, 1996.

[20] B. Lancaster, Rainwater Harvesting for Drylands and Beyond, Volume 2: Water-Harvesting Earthworks, Second Pri. Tucson, Arizona: Rainsources Press, 2010.

[21] A. Olley, "Greenhouse Tomato Production in Cocopeat Turkey," Andrew Olley Consult., pp. 1-57, 2009.

[22] M. Suzuki et al., "Effects of relative humidity and nutrient supply on growth and nutrient uptake in greenhouse tomato production," Sci. Hortic. (Amsterdam)., vol. 187, pp. 44-49, 2015.

[23] S. E. Wortman, "Crop physiological response to nutrient solution electrical conductivity and $\mathrm{pH}$ in an ebb-and-flow hydroponic system," Sci. Hortic. (Amsterdam)., vol. 194, pp. 34-42, 2015. 